University of Nebraska - Lincoln

DigitalCommons@University of Nebraska - Lincoln

USDA National Wildlife Research Center - Staff Publications
U.S. Department of Agriculture: Animal and Plant Health Inspection Service

July 2002

\title{
Wildlife damage management research needs: perceptions of scientists, wildlife managers, and stakeholders of the USDA/ Wildlife Services program
}

\author{
Richard L. Bruggers \\ USDA/Wildlife Services, National Wildlife Research Center \\ Richard Owens \\ USDA/Wildlife Services \\ Thomas Hoffman \\ USDA/Wildlife Services
}

Follow this and additional works at: https://digitalcommons.unl.edu/icwdm_usdanwrc

Part of the Environmental Sciences Commons

\begin{abstract}
Bruggers, Richard L.; Owens, Richard; and Hoffman, Thomas, "Wildlife damage management research needs: perceptions of scientists, wildlife managers, and stakeholders of the USDA/Wildlife Services program" (2002). USDA National Wildlife Research Center - Staff Publications. 468.

https://digitalcommons.unl.edu/icwdm_usdanwrc/468
\end{abstract}

This Article is brought to you for free and open access by the U.S. Department of Agriculture: Animal and Plant Health Inspection Service at DigitalCommons@University of Nebraska - Lincoln. It has been accepted for inclusion in USDA National Wildlife Research Center - Staff Publications by an authorized administrator of DigitalCommons@University of Nebraska - Lincoln. 


\title{
Wildlife damage management research needs: perceptions of scientists, wildlife managers, and stakeholders of the USDA/Wildlife Services program
}

\author{
Richard L. Bruggers ${ }^{\mathrm{a}, *}$, Richard Owens ${ }^{\mathrm{b}}$, Thomas Hoffman ${ }^{\mathrm{c}}$ \\ "USDA/Wildlife Services, National Wildlife Research Center, 4101 LaPorte Ave, Fort Collins, CO 80527, USA \\ ${ }^{b}$ USD A Willife Sertices, Eastern Region. 920 Main Campus Drive, Sulte 200, Raleigh, NC 27606, USA \\ ${ }^{\mathrm{c}}$ USDA/Wildife Services, Western Region. $12345 \mathrm{~W}$, Alameda Parkwar, Suite 204, Lakewood, CO 80228. USA
}

\begin{abstract}
This paper presents the results of a nationwide research needs assessment of the important wildlife-human conflict issues and associated research needs of the USDA/APHIS-Wildlife Services (WS) program and its stakehoiders. Thirty-six WS State Directors, 23 WS/National Wildlife Research Center (NWRC) scientists and 6 members of the National Wildife Services Advisory Committee (NWSAC) to the US Secretary of Agriculture responded to a request for participation. This paper compares these current research needs with previous regional and national research needs assessments for wildlife damage management in the United States. Important national problems identified included issues related to aviation, timber, agriculture, aquaculture, and livestock industries, as well as wildlife-borne diseases, invasive species, and overabundant wildife populations. This assessment provides useful input, along with legislative and administrative guidance, to NWRC for allocating resources to specific research projects that address the WS program's needs for knowledge and new methods. Published by Elsevier Science Ltd.
\end{abstract}

Keywords: Wildlife damage; Research needs; Wildlife management

\section{Introduction}

Wildlife is highly valued as a resource by society, but increasingly, wildlife and society are coming into conflict. Anything that wildlife does to cause human injuries or illness, loss of economic productivity, physical danger, or a reduction in quality of life or well-being is considered to be wildlife damage (Conover, 2001). In recent years, the adverse economic impacts of wildlife to society have been dramatically documented. Wywialowski (1994) reported that, of 13,000 respondents to a survey of 20,000 agriculture producers, over $55 \%$ had experienced wildlife damage collectively valued at $\$ 461$ million in 1989 . In the 1990 s, US agricultural producers and metropolitan households spent $\$ 2.5$ billion (Conover, 1998) and $\$ 5.5$ billion (Conover, 1997), respectively, to manage wildlife related problems. Messmer (2000) cited many specific studies that documented the economic losses and adverse impacts caused by wildlife to livestock, timber, agricultural crops,

\footnotetext{
* Corresponding author.

E-mail address: richard.l.bruggers@aphis.usda.gov (R.L. Bruggers).
}

fruit, nuts, vegetables, human health and safety, vehicles and aircraft, wildlife bites and disease transmissions, and discussed the emerging conflicts and challenges of humanwildlife conflict resolution. Conover et al. (1995) had previously developed estimates of the economic and social costs of many of these problems. Fall and Jackson (2000) contended that, while the number of species and conflict situations are growing, the constraints placed on managers also are on the increase, resulting in fewer options being available to resolve and manage these problems. The heightened awareness and importance of this issue has been exemplified by the establishment in 1994 of a 'Wildlife Damage Working Group' within The Wildlife Society (currently the largest of any TWS working group), and by recent volumes of the Wildlife Society Bulletin being devoted to specific human-wildlife conflict issues, including deer overabundance [1997, Vol. 25(2)], the role of hunting and trapping in harvest management [2000, Vol. 28(4)] and the impacts of predators on avian species [2001, Vol. 29(1)]. Wildlifehuman conflict issues have existed for many years, clearly are increasing, and will be around for many years to come. This situation is the result of five major trends that can be 
expected to continue through the coming years: (a) increasing suburban development; (b) adaptable and over abundant wildlife species; (c) a shift in public attitudes towards the welfare of animals; (d) increasing media interest in wildlife issues; and (e) advances in wildlife science and technology (USDA, 1998). As a result, the need for effective, environmentally safe, science-based wildlife damage management methods and strategies is critical.

Fall and Jackson (1998), Curnow (2001) and Conover (2001) provide insights and discussions into the history of wildlife damage management and the trends, changes and progress that have occurred in the field of wildlife damage management and methods development research. Several state agencies, universities, and private organizations have been or are involved in some way in research at local, regional, national, and international levels to define, understand, and resolve wildlife-human conflicts. The enabling acts, legislative mandates and mission statements of these entities often define their specific research directions. Direct US government involvement in wildlife damage management began in 1885 with the creation of the USDA Section of Economic Ornithology. The US Department of Agriculture's (USDA) enabling legislation for this program, the Animal Damage Control Act of 1931, authorized USDA to conduct activities to control injurious animals, but also placed considerable emphasis on research programs to develop new control methods at government laboratories (Fall and Jackson, 1998). With this legislation, the USDA/Animal and Plant Health Inspection Service (APHIS)/Wildlife Services (WS) program has direction to "provide federal leadership in managing problems caused by wildlife" (USDA, 1998).

\subsection{Wildlife Services operations}

The WS operational program is comprised of about 1200 employees, located or working in every state throughout the nation. Overall program direction is provided by a WS Deputy Administrator in Washington, DC, Regional Directors for the eastern and western US, and 38 State Directors. Several State Directors have multi-state authority and these individuals supervise federal and state field personnel and wildlife specialists. The WS operational program works with other federal and state agencies, as well as county and municipal governments, to assist private homeowners, farmers, ranchers and others to manage wildlife damage concerns. These concerns are diverse and a survey of these State Directors to determine their perceptions of research needs can be considered reflective of the pressing wildlifehuman conflict issues within their states and or regions. One important function of the periodic WS research needs assessment (RNA) is to identify and prioritize these concerns so that scientific information and new or improved methods can be developed to address the most pressing wildlife issues.

\subsection{Wildlife Services research}

National Wildlife Research Center (NWRC), which is dedicated to finding solutions to wildlife damage issues, functions as the research arm of the USDA WS program. Curnow (1996) has summarized the history of the Center within the USDA and the US Department of Interior (USDI). The NWRC mission is focused exclusively on research and methods development for wildlife damage management, with a special emphasis on methods for use by WS operational personnel. At NWRC headquarters in Fort Collins, Colorado, and at field stations in nine states, NWRC has a staff of about 150 employees with expertise in wildlife biology and a wide diversity of other specialized disciplines. NWRC research focuses on developing socially acceptable and economically feasible methods for reducing wildlife damage impacts on agriculture, human health and safety and threatened and endangered species, while minimizing risks for humans, wildlife, and the environment (USDA, 1999). The NWRC is expected by Congress, the WS program and its stakeholders, and the general public to address many historical and traditional issues, as well as an increasing number of new, emerging and diverse wildlife damage conflict situations. This paper describes one process, the RNA that the WS program has used since its 1985 transfer into USDA to identify, prioritize, and commit funds to implement an integrated, multidisciplinary research program to provide scientific information and solutions for wildlife damage problems.

\section{Research needs assessment}

\subsection{Background}

After its 1985 transfer from USDI/Fish and Wildlife Service into APHIS, WS initiated an extensive strategic and future planning effort in a number of important areas (Acord et al., 1994). One such area related to methods development. In 1989, APHIS, in a strategy to align WS program research with WS operations and stakeholder needs, initiated a policy by which the local, regional and national research needs of the WS program would be identified. A national RNA survey of WS State Directors identified a matrix of specific problem species groups and the specifically affected resource groups (Packham and Connolly, 1992). In 1989, a decision also was made to conduct these national assessments about every 5 yr. Additional WS program-wide RNAs were completed in 1996 (Bruggers et al., 1996) and 2001 (Bruggers et al., 2001). This paper reports the $2001 \mathrm{RNA}$, provides a prioritization of those considered most important by the WS program, and compares current results with previous assessments in the United States.

Although the WS program has a process to identify and prioritize important research, NWRC does not have complete discretion as to which areas of wildlife-human conflict 
research it addresses. Much of the Center's research (and even the location of its field stations) can be and has been mandated by Congress. As examples, Congress has directed NWRC to conduct research on bird damage to aquaculture and sunflowers, rodent damage to agriculture in Hawaii, and even to develop a specific chemical as a waterfowl reproduction inhibitor. Other Congressional directives have resulted in the establishment of NWRC field stations and research programs in Mississippi, North Dakota, Hawaii, and Pennsylvania to address wildlife damage needs. Congress has also directed that at least $50 \%$ of the Center's research effort should be devoted to development of non-lethal management methods.

In 1996, NWRC implemented a multiyear, multidisciplinary project management system to specifically address areas of high priority research as identified in the 1996 RNA. These projects are of 3-5 yrs in duration, have clearly stated goals and objectives, identify projected milestones and expected outputs, and require mid-term and final project reviews, as well as annual progress updates. Project planning, implementation, and reviews routinely include input from WS operations personnel, outside scientists and stakeholders. The NWRC program uses the RNA not only to achieve specific research objectives within broader administrative directives but also to develop new research projects to address important, emerging wildlife-human conflict issues. For example, as existing, center projects are completed, new projects that address different aspects of some of the same issues, or entirely new areas of research, are developed to address research needs identified in the most recent assessment.

\section{The 2001 RNA and prioritization process}

In February 2001, WS program administrators requested State Directors and NWRC scientists to identify their most important research needs based on problem species and affected resources, magnitude of the problem, and importance of research. In addition, members of the National Wildlife Services Advisery Committe (NWSAC), an independent, Federal advisory committee, composed of representatives of organizations such as livestock and agricultural producers, universities, animal interest groups, state agencies, and private pest control companies - all organizations that have an interest in USDA wildlife damage management issues-were asked to respond to the same request. The NWRC received 188 submissions from 26 WS State Directors representing 36 eastern and western states, 23 NWRC scientists, and 6 NWSAC members. After each of the 188 submissions was rewritten into a standard format and duplicate submissions were removed, 103 needs emerged. These diverse needs were then categorized by research related to wildlife species groups, affected resource, threatened and endangered species, wildlife disease, wildlife population-models/census/economics, chemical products/registration, and documentation/information (Table 1). This extensive list of specific research needs was further prioritized into a shorter list of high priority areas, using the following criteria: state, regional, or national importance; perceived value and/or magnitude of the resources impacted, damaged, or lost; perceived importance to stakeholders; current availability of existing information, methods, and/or solutions that simply need refinement versus the need for new information, methods, and/or solutions; need for immediate versus future information, methods, and/or solutions; and the extent of past research efforts versus the need for new research directions.

\section{Results and discussion}

Table 2 presents a compilation of the 13 highest priority research areas identified for the WS program (Bruggers et al., 2001). Most of these priority research areas also identify the specific resources affected, possible research approaches, and important information methods and even products desired. In gencral, the 2001 research needs centered on issues related to: (a) bird damage to agriculture and aquaculture; (b) waterfowl, goose, and vulture impacts in urban/suburban situations; (c) wildlife problems at airports; (d) predator impacts on livestock, other wildlife, and human health and safety; (e) mammal damage to forest, riparian, and agriculture resources; ( $\mathrm{f}$ ) wildlife disease transmission; ( $\mathrm{g}$ ) invasive species; and $(\mathrm{h})$ census methods for management of overabundant species. Woven through these issues were recommendations to study the economics of damage by a variety of species, to develop and register non-lethal chemical products, and to improve information dissemination. The importance of wildlife damage management information transfer within the WS program was documented recently by Johnston et al. (1999) and was further stressed in the results of this assessment.

A few clarifications to the list in Table 2 are needed. First, only proposed NWRC research to be funded by direct legislative appropriation to APHIS/WS has been included. Therefore, research to control Brown Treesnakes on Guam, for example, which NWRC conducts with external funds, is not listed. Second, the WS program, and as a result the NWRC research, is not routinely involved in a number of urban wildlife damage issues, for example commensal rodent control, as they are left to pest control operations. Third, considerable product development research is identified as required to address the diverse bird and mammal damage problems. Such products include contraceptives, sterilants, and vaccines; non-lethal repellents such a methyl anthranilate; the avian toxicant, DRC-1339 (3-chloro- $p$-toluidine hydrochloride); toxicant ejector registrations for use in protecting natural resources; alternative rodenticides and odor and taste attractants; and live capture devices, remote trap monitors, and trap pan tension devices. Development of such products and techniques are and have been expected 
Table 1

Summary of 103 research needs identified by Wildlife Services Eastern and Western Region State Directors, National Wildlife Research Center scientists, and the National Wildlife Services Advisory Committee in 2001 Wildife Services research needs assessment

\section{Bird research}

Aquaculture

Determine the populations and impacts of double-crested cormorants and pelicans on sport fish and other natural resources.

Implement a strategy for controlling double-crested cormorant populations on breeding grounds to minimize damage to the aquaculture industry. Clarify the local movements of American White Pelicans in and around aquaculture facilities as related to their possible transmission of catfish diseases.

Determine the economic impact and investigate methods to protect freshwater and marine aquaculture from fish-eating birds.

Develop methods to test behavior-contingent disruptive stimulus devices on birds, primarily in aquaculture or crop depredation situations.

Aliation

Continue to work on solutions to bird and other wildlife problems at airports.

Continue investigating and developing non-lethal methods (c.g., habitat management techniques and recommendations) to reduce wildlife hazards at airports nationwide.

Maintain and expand the National Wildlife Strike Database (NWSD).

Evaluate desert environments as they pertain to wildlife-aviation strike hazards.

Blackbirds/corvids (crows and ravens)

Develop new/improve existing methods (e.g., repellents, toxicants, Avitrol, pyrotechnics, harassment, barriers, reproductive inhibition) to mitigate the impact of blackbird, crow, and staring damage to sunflowers, sprouting and ripening rice and corn, other small grain crops, and fruit crops.

Develop methods to estimate the mortality of blackbirds during operational use of chemical control methods.

Better understand the roosting preferences and behaviors of urban crows and investigate and develop aversive methods to manage urban/suburban bird roosts involving crows, starlings, grackles, pigeons, cowbirds and blackbirds.

Develop repellents for ravens and crows.

Waterfowl/gulls/terns

Evaluate the effectiveness of existing and new tools (e.g.. lasers, collies, and habitat management) for waterfowl (i.e., geese and ducks) and develop other more efficient, long-lasting methods to address issues associated with human health and safety, agriculturc, urban property (landscapes, rooftops and landfills), and natural resources (shoreline erosion from overgrazing).

Determine the severity of and develop methods to reduce the impacts to winter wheat and other crops by grazing waterfowl, especially Canada geese.

Evaluate the effectiveness of relocating urban/suburban Canada geese and determine their survival and return rate.

Develop and evaluate methods to manage guil and tern populations causing problems to endangered salmon species at hydroelectric structures.

Other birds/situations

Evaluate repellents for parrots and cardinals in seed corn on Hawaii/Pacific Islands.

Develop methods to manage damage by birds to vineyards.

Develop tools to manage woodpecker damage to structures, utility poles, and citrus, and raven damage to citrus.

Develop methods (e.g., lasers and infrared technologies) to reduce eagle predation on livestock.

Continue to develop methods to disperse black and turkey vulture roosts and manage their damage to livestock, property, communication towers, homes, and water craft.

Develop a decision model as a tool to decide if depopulating vulture roosts is economically feasible.

Increase activities related to the protection of neotropical songbirds from competition with blackbirds and other overabundant and nuisance wild and feral domestic animals.

Conduct applied research that investigates the important factors infiuencing aversions (e.g., flavors and social facilitation) on birds.

Evaluate the impact on birds of chemicals used for insect control.

Mammal research

Aquatic mammals

Evaluate beaver populations and develop existing (e.g., repellents, barriers) and alternative (e.g., relocation) management practices to reduce their damage to timber, crops, roadways, railroads, housing developments nationwide.

Determine the role of beaver populations in salmon ecology and develop management methods.

Conduct research to identify, evaluate, and improve the methods, materials and devices needed to reduce and monitor nutria and muskrat damage to marsh ecosystems and agriculture, including developing ecologically sound and cost-effective integrated management strategies.

\section{Forest resources}

Continue to develop alternative methods and strategies to protect timber and forest resources from wildlife damage nationwide.

Determine whether bear damage to timber is a learned behavior or an evolutionary trait.

Improve technology used in non-lethal wildlife relocation efforts (e g., bears) related to method of capture and transport, distance, time-of-day, habitat, and territorial insertion.

Develop effective, environmentally safe toxicants and delivery systems for forest mammal damage management.

\section{Predators (livestock)}

Develop predator management programs that include state-of-the-art technology and cutting edge science.

Assess strategies and programs and develop methods to manage coyote predation on livestock.

Evaluate sheep losses to coyotes in areas with and without operational control. 
Table 1 (continued)

Develop both non-lethal and lethal tools to selectively target and remove specific predators whose territories overlap sheep pastures in an economic, efficient. and humane rianner.

Develop lethal or non-lethal control methods that are effective against territorial, dominart coyotes (alphas) who have previously been exposed to control.

Continue to develop altemative predator eapture devices, with a focus on decreasing injury rates.

Develop new, effective, non-lethal capture techniques and management strategies for predators (e.g., coyotes, wolves, fox, bear and mountain lions).

Re-evaluate the capture efficiency and non-target impacts of the foothold traps and snares currently being used to capture coyotes, foxes, and raccoons.

Develop new technologies to address $24 \mathrm{~h}$ trap check requirements.

Develop live traps for larger mammals such as coyotes, lions, and bobcats.

Develop techniques for remote triggering of coyote calling devices.

Develop new predator management tools to replace traps and toxicants on public lands

Evaluate damage management methods for established wolf populations.

Determine the population dynamics of expanding cougar populations.

Rodents

Continue development of tools and techniques for use in integrated pest management strategies for ground squirrels, prairie dogs. pocket gophers, voles, and deer mice

Develop toxicants, chemical and physical repellents to prevent gnawing, contamination, structural damage, and crop/food loss damage by rodents.

Develop and refine ccologically sound and cost-effective techniques for rodent control in agriculture and native ecosystems in Hawaii and islands in the Pacific, Indian, and Caribbean Oceans.

Other mammals/situations

Conduct applied research that investigates plant herbivore interactions, that is the natural defenses of plants to wildlife.

Develop non-lethal methods to reduce ungulate deer and elk damage in agricultural and urban landscapes.

Conduct research to determine the population, range, density of the nine-banded armadillo in Florida, quantify their ecological and economic impacts and identify, cvaluate, and improve methods to reduce its damage to ecosystems and agriculture.

Conduct research to determine the population size, range, density of wild pigs throughout their range in the US, quantify their ecological/economic impacts, evaluate, and improve the methods to reduce and monitor pig damage to ecosystems and agriculture.

\section{Threatened and endangered species}

Develop methods to detect and manage the impact of mammalian predators on T\& E wildlife species, specifically red fox predation on rails and terns, and rat, feral cat and island fox predation on shrikes.

Examine the growing conflict and develop basic and applied strategies to reduce mammalian predation on threatened and endangered species. Develop new, effective and efficient methods and assess management strategies to reduce risks that predators (e.g., coyotes, wolves) pose to threatened and endangered species.

Determine the indirect benefits to pronghorn fawn survival rates of predator management programs.

Evaluate all impacts, including the incidental or coordinated beneficial impacts on native prey, from the use of integrated wildlife damage management techniques.

\section{Invasive species}

Begin to document the extent of invasive vertebrate species nationwide, beginning within each state, and initiate research into invasive species management in the US.

Develop options for managing invasive and exotic species problems in the US.

Develop and refine control techniques for the Brown Treesnakes on Guam, including effective aerial bait delivery systems and artificial attractants.

Evaluate the efficiency of canines to detect Brown Treesnakes under the current passive detection protocol on Guam.

Develop methods to monitot and control introduced vertebrate species that have impacted Hawaiian agriculture and natural resources, including tree frogs, parrots, axis deer and smail predators.

Develop crab/pig resistant bait stations for anticoagulant use on rats and mongoose in island environments.

\section{Chemical products and registration}

Continue to assure use and improvernent of existing tools and chemical products.

Develop an alternative chemical and delivery system to the M-44.

Evaluate registration of M-44 for protection of natural resources (mammalian and avian).

Develop odor and taste attractants to improve rodenticide, avicide, and contraceptive baiting efficacy, safety and selectivity toward target species.

Evaluate registration of $\mathrm{DRC}-1339$ for use in protecting bee boards from corvids (magpies, crows, ravens).

Develop a replacement avicide for LRC-1339.

Determine the adsorption, distribution, metabolism, and excretion of alpha chloralose in target pest bird species related to the 30 day FDA-imposed hunting moratoriuril on its use.

Conduct research to develop more bird repellent and toxicant registrations.

Develop efiective microencaps ulation techniques for rodenticides.

Develop a more effective tranquilizer trap device for expanded widespread use to include wolves and feral dogs.

Develop effective baits to live trap armadillos in urban areas.

Develop an improved bait for use in removing starlings and blackbirds from feedlots, deiries, and staging areas. 
Table 1 (continued)

Identify and evaluate alternative products, such as repellents, attractants, and or animal drugs for possible registration with EPA and FDA. Develop new ways to formulate and deliver products more efficiently for use by wildlife damage managers.

Develop a non-toxic, cost-effective blackbird repellent for protecting rice crops.

Explore and develop genetic plant and prey species alteration as a means of reducing the attractiveness of crop and livestock resources to problem wildlife.

Register ROZOL grain-bait for prairie dog control.

\section{Wildlife disease}

Evaluate the significance of and develop methods to reduce the risk of disease transmission by crows, starlings, geese, and other avian wildife to humans and livestock.

Determine the impact of and develop methods to reduce human health and safety impacts caused by waterfowl, especially Canada geese, in urban/suburban areas.

Increase research on reproductive inhibitors and oral vaccines for wildlife disease control.

Evaluate the relevant aspects of demography, behavior, and movements of raccoons as they relate to oral rabies vaccination programs.

Develop methods to manage the impact of rabies and other discases transmissible from wildlife to humans.

Obtain information on gray fox home range and population dynamics to develop improved oral rabies vaccine baiting strategies.

Develop methods to survey and monitor emerging wildlife diseases that pose potential threats to human health and safety.

\section{Wildlife population-models/census/economics}

Continue research on impacts and efficacy of predator control, including cost-benefit analyses and intra-and inter-species impacts nationwide. Continue to develop methods to census wildlife populations (e.g., coyotes, foxes, feral hogs, armadillos, and raccoons) related to increased ability to implement and improve control programs to protect threatened and endangered species.

Develop a standardized survey to assess the distribution, magnitude, and characteristics of wildlife damage problems associated with urban/suburban areas.

Develop methods to census and investigate populations of problem wildlife species (e.g., coyote, beaver, bear, mountain lions. blackbirds, gulls, cormorants, and geese) related to management and NEPA requirements.

Develop methods to monitor pest wildlife populations related to economic impacts, management effectiveness, and environmental concerns. Develop methods that the WS program can use to report the estimated "take" associated with different damage control measures.

Develop quantitative and economic evaluations of current applied wildlife damage methods and tools (e.g., aerial hunting) under operational circumstances.

Develop a better understanding of population dynamics and economic impact of the primary species to which WS directs its operational programs.

Devise computer-based techniques to evaluate the costs benefits of preventative and corrective approaches, tools, and activities associated with the species most frequently managed by WS and its stakeholders.

Develop bioenergetic models to estimate economic impacts of blackbirds and other overabundant and nuisance species relative to cost-benefit analyses, management programs, and environmental issues.

Improve the understanding of carnivore depredations through modeling and develop new and modified management strategies.

Develop genetic markers for use in censuring populations and identifying individual animals for improved management of pest wildlife.

Conduct economic analyses of the (1) value of wildlife to non-consumptive users, (2) livestock losses versus control implementation by WS operations, (3) impacts of lethal control on ecosystem health and integrity, and (4) aerial gunning program of WS operations.

Documentation/information

Index APHIS/WS/NWRC website to "hit" for searching by species (e.g. coyotes, gulls, etc.)

Assemble a product-specific database of commercial wildlife repellents, with relevant research citations, as an aid to wildlife managers nationwide.

Conduct human dimension research to assess the impact of wildlife damage management programs on the public.

Evaluate public attitudes toward Wildlife Services and study the effects of the WS national education program on attitudes towards wildlifehuman conflicts.

Assess potential wildlife "growth" areas to determine the need and extent of emerging wildlife damage issues.

Document calf losses to natural causes versus coyote predation.

Document the benefits of predator control to enhance wildlife populations.

Communicate new research developments more effectively, by improving technical and educational outreach program and information transfer between research and operations.

outputs of Center research, as evidenced by those non-lethal techniques listed in Table 3. Fourth, a number of the priority research areas for the WS program expressed in this 2001 RNA are very similar to those identified in earlier assessments. Thus, the NWRC already has in place several projects that will immediately address these assessment results. And finally, the identified documentation needs that emerged from this survey will be addressed by the NWRC, and by working with the WS program and APHIS Legislative and Public Affairs personnel, as opportunities arise.

\subsection{Comparison of WS program and Advisory Committee input}

The research needs identified by the WS program in 1989,1996 and 2001 are relatively invariant. During each 
Table 2

Thirteen highest priority research issues determined from 103 specific identified needs in the 2001 Research Needs Assessment conducted by the Animal and Plant Health Inspection Services Wildlife Services Program

\section{Birds}

Improve existing and investigate new methods to protect agricultural crops (for example: sunflower, sprouting and ripening rice) from blackbird damage.

More specifically, needs were identified related to developing non-lethal techniques (for example: repellents. frightening devices, barrier, habitat management, and reproductive inhibitors); improving lethal chemical tools (for example: improve baiting strategy and enhance acceptability of DRC 1339-Starlicide); and developing methods to estimate mortality or "take" of blackbirds during operational use of these tools for blackbird damage control in sunflowers and rice.

Conduct research on the impacts of fish-eating birds (primarily double-crested cormorants and American white pelicans) to the aquaculture and sport fish industries.

More specifically, needs were identified related to understanding cormorant depredation and impacts to sport fisheries (for example: crappie, bass, and walleye), the crawfish industry, and other natural resources (for example: roosting vegetation), and American white pelican impacts on sport fisheries. their local movement patterns in commercial aquaculture areas relative to both damage and transmission of catfish diseases; and developing new, non-lethal methods (for example: repellents, behavior contingent disruptive stimuli) to reduce their adverse impacts to commercial and sport fishery production.

Investigate hazards, solutions, and straiegies to resolve bird and other wildlife problems at airports.

More specifically, needs were identified related to continuing investigations of non-lethal methods, specifically habitat management techniques, and initiating new investigations of non-traditional ecosystems, such as desert environments, as they relate to wildlife-aviation strike hazards. Investigate the roosting preference, behavior, and dispersal techniques for crows and ravens in urban/suburban environments.

Investigate and develop new and improve existing tools and strategies to resolve the impacts of geese, gulls, and terns in a variety of urban/suburban situations.

More specifically, needs were identified related to developing efficient, long-lasting damage management techniques (for example: barriers, harassment and hazing methods, contraceptives, Avitrol, egg removal, and repellents), and addressing issues related to geese and human health and safety (for example: potential disease transmission), gulls and urban property damage (for example: using rooftops and landfills), and terns and natural resource impacts (for example: predating salmon smolt).

Conduct research into understanding the problems and developing methods (for example: harassment, taste repellents. toxicants) to reduce the negative impact of black vultures and turkey vultures on livestock production and property (for example: homes, watercraft, and communication towers).

\section{Mammals}

Develop methods to protect timber and forest resources from wildlife damage.

More specifically, needs were identified related to evaluating existing and identifying new repellents and barriers, and assessing the economic implications of various mitigation methods and strategies.

Conduct research to understand and resolve the impact of beavers on aquatic ecosystems.

More specifically, needs were identified related to developing methods to census local beaver populations, describe and quantify their economic impacts, and evaluating existing (for example: repellents, barriers, lures, and toxicants) and alternative (for example: relocation) management practices to reduce their damage to forest, agriculture, urban/suburban, and riverine environments.

Evaluate and develop tools and techniques for use in integrated pest management strategies for rodents in both agricultural and native habitat ecosystems.

More specifically, needs were identified related to evaluating ecologically sound and economicaliy feasible methods (for example: repellents, barriers, toxicants, odor and taste attractants, micro-encapsulation methods) to reduce negative impacts of prairie dogs, rats, pocket gophers, and ground squirrels.

Conduct behavioral and techniques development research for canids as related to developing effective predation damage management programs for livestock in agricultural situations and for protecting human health and safety in urban/suburban situations.

More specifically, needs were identified related to improving existing and developing new alternative tools, using state-of-the-art technologies (for example: improved capture devices such as snares and lives traps, reproductive inhibition techniques, vaccines and associated delivery systems, as well as selective attractants and repellents) for primarily coyotes, cougars, and bears in agricultural settings, and coyotes and fox in urban/suburban settings.

Examine the growing and expanding negative impact of predators (for example: coyotes, foxes, wolves, and raccoons) on wildlife resources (for example: deer and antelope), including, but not limited to threatened and endangered species (for example: sage grouse, turtles, terns, and rails). More specifically, needs were identified related to evaluating existing and developing new, effective predation damage management tools and strategies for use in these expanding, predator-wildlife conflict situations.

\section{Wildlife diseases and population monitoring}

Develop methods to survey and monitcr emerging wildlife diseases and reduce the risks of the transmission of those that pose a threat to hurnan health and safety and livestock production.

More specifically, needs were identified related to understanding the demography, movements and behavior of raccoons and foxes as related to oral rabies vaccination programs, and deer and cattle as related to bovine tuberculosis transmission; and developing methods (for example: barriers, reproductive inhibitors, and vaccines) to reduce the risk of disease transmission.

Develop methods to better monitor problem wildlife species populations as related to their economic impact, management effectiveness, and environmental mandates (for example: NEPA requirements).

More specifically, needs were identified related to improving and/or developing practical methods to census overabundant wildlife populations, assess damage, determine "take" and quantify the effectiveness of management strategies (for example: nor-lethal versus lethal methods), with particular emphasis placed on those species most often addressed by the WS program (for example: coyotes, blackbirds, and beavers). 
Table 3

Selected recent and emerging new non-lethal methods researched and or developed by National Wildife Research Center to help resolve wildlife damage conficts

\section{Recent non-lethal methods:}

Methyl anthranilate as a goose repellent

Tranquilizer trap device for coyote capture systems

Alpha-chloralose for waterfowl capture

Foothold snares for coyote capture

Breakaway snare locks for non-target animal release

Electronic monitor for predator capture systems

Guarding llamas for livestock protection

Improvements to leg-hold traps to reduce injuries

Cormorant roost harassment for catfish aquaculture protection

Lime repellent for geese on turf

Airport landscape management techniques for bird hazard reduction

Bird management on and near airports (gull colony management)

Herbicide for reducing blackbird roosting habitat near sunflower fields

Methiocarb aversive agent for raven predation of Least Tern eggs

Radar-activated bird hazing systems

Textural and taste repellents for tree/shrub protection from beaver and deer

Silt fencing to reduce gull and tern nesting

Lasers as bird roost dispersal technique

\section{Emerging non-lethal methods:}

Brown Treesnake repellents

Reproduction control in territorial coyote for livestock protection

Immunocontraceptive vaccines for selected wildlife species

Predator activated aversion systems for livestock protection

Anthraquinone repellent for geese and blackbirds

Bird repellent protection of fruits, vegetables and grains

Timber management strategies for bear damage to Douglas fir trees Improved predator live-capture systems

Physical barriers for pocket gopher damage management

Reproduction control in overabundant geese

Vulture effigies to disperse vulture roosts

Genetic markers for identifying wildlife populations

Cell culture techniques to screen chemical repellents

assessment, wildlife damage to agriculture, aquaculture, timber, livestock and aviation industries were identified as critical areas requiring research (Table 4), and blackbirds, waterfowl, cormorants, gulls, canids, ungulates, beavers and rodents were identified as the principal wildlife species groups impacting those resources (Table 5). However, as Tables 4 and 5 also indicate, over the $13 \mathrm{yr}$ since the 1989 RNA, several new wildlife damage areas of concern have emerged while other areas have declined in priority. In general, these areas of concern have involved avian rather than mammalian species. For example, research needs related to fruits (berries), gardens and forage crops have been replaced by research needs related to ecosystem health, water quality, wildlife and rare species resources. Similarly, research needs related to the impacts of passerine birds on crops have been replaced by needs related to crows, ravens, vultures and pelicans.

As in past assessments there were differences between WS eastern and western states in their highest priority wildlife damage problems (Tables 6 and 7). WS Eastern Region
Table 4

Principal resource groups prioritized by Wildlife Services as most affected by wildlife in three Wildlife Services Research Needs Assessments

\begin{tabular}{llll}
\hline Resource group & $1989^{a}$ & 1996 & 2001 \\
\hline Grain & $\mathrm{X}$ & $\mathrm{X}$ & $\mathrm{X}$ \\
Nuisance & $\mathrm{X}$ & & \\
Livestock & $\mathrm{X}$ & $\mathrm{X}$ & $\mathrm{X}$ \\
Structure & $\mathrm{X}$ & & \\
Aircraft & $\mathrm{X}$ & $\mathrm{X}$ & $\mathrm{X}$ \\
Fish (aquaculture) & $\mathrm{X}$ & $\mathrm{X}$ & $\mathrm{X}$ \\
Forestry & $\mathrm{X}$ & $\mathrm{X}$ & $\mathrm{X}$ \\
Fruit/berry & $\mathrm{X}$ & & \\
Forage crop & $\mathrm{X}$ & & \\
Truck/garden crop & $\mathrm{X}$ & & $\mathrm{X}$ \\
Water quality & & $\mathrm{X}$ & \\
Bait fish/tropical fish & & $\mathrm{X}$ & $\mathrm{X}$ \\
Sport fisheries & & & $\mathrm{X}$ \\
Thrcatened/endangered species & & & $\mathrm{X}$ \\
Wildlife & & & $\mathrm{X}$ \\
Riverine ecosystem & & & $\mathrm{X}$ \\
Native ecosystem & & &
\end{tabular}

${ }^{a}$ The 1989 list reflects the national ranking of the top 10 principal resource groups impacted by wildlife as identified in Packham and Connolly (1992). The remaining resource groups in the list were identified in subsequent RNAs.

Table 5

Principal species groups ${ }^{\text {a }}$ identified by Wildlife Services during three Research Needs Asscssments

\begin{tabular}{llll}
\hline & 1989 & 1996 & 2001 \\
\hline Birds & & & \\
Blackbirds/starling & $\mathrm{X}$ & $\mathrm{X}$ & $\mathrm{X}$ \\
Waterfowl & $\mathrm{X}$ & $\mathrm{X}$ & $\mathrm{X}$ \\
Wading birds/cormorant & $\mathrm{X}$ & $\mathrm{X}$ & $\mathrm{X}$ \\
Gull & $\mathrm{X}$ & $\mathrm{X}$ & $\mathrm{X}$ \\
Pigeon & $\mathrm{X}$ & & \\
Woodpecker & $\mathrm{X}$ & & \\
Crow/raven & $\mathrm{X}$ & & $\mathrm{X}$ \\
Robin & $\mathrm{X}$ & & \\
Sparrow/finch & $\mathrm{X}$ & & \\
Raptor & $\mathrm{X}$ & & \\
Vulture & & $\mathrm{X}$ & $\mathrm{X}$ \\
Sandhill crane & & $\mathrm{X}$ & \\
American white pelican & & & $\mathrm{X}$ \\
Mammals & & & \\
Canid & $\mathrm{X}$ & $\mathrm{X}$ & $\mathrm{X}$ \\
Ungulate & $\mathrm{X}$ & $\mathrm{X}$ & $\mathrm{X}$ \\
Beaver & $\mathrm{X}$ & $\mathrm{X}$ & $\mathrm{X}$ \\
Bear & $\mathrm{X}$ & & \\
Skunk & $\mathrm{X}$ & & \\
Raccoon & $\mathrm{X}$ & $\mathrm{X}$ & $\mathrm{X}$ \\
Vole & $\mathrm{X}$ & & $\mathrm{X}$ \\
Prairie dog/ground squirrel & $\mathrm{X}$ & & \\
Marmot & $\mathrm{X}$ & & $\mathrm{X}$ \\
Mountain lion & $\mathrm{X}$ & & \\
\hline & & & \\
\hline
\end{tabular}

${ }^{a}$ Reflects the rank order of the 10 most important bird and mammal species groups identified in Packham and Connolly (1992).

"Identified as "rodents" in 2001 RNA. 
Table 6

Industry or resource group affected by wildlife as listed by Wildlife Services State Directors and National Wildlife Research Center scientists in the $200 \mathrm{l}$ Wildife Services Research Needs Assessment ${ }^{2}$

\begin{tabular}{|c|c|c|c|c|}
\hline Industry resource & $\begin{array}{l}\text { Eastern } \\
\text { region }\end{array}$ & $\begin{array}{l}\text { Western } \\
\text { region }\end{array}$ & $\therefore W R C$ & Total \\
\hline Aviation & 2 & 3 & 3 & 8 \\
\hline \multicolumn{5}{|l|}{ Predators } \\
\hline Livestock & 3 & 6 & 7 & 16 \\
\hline Wildlife & 0 & 4 & 3 & 7 \\
\hline \multicolumn{5}{|l|}{ Threatened \& endangered } \\
\hline species & 0 & 2 & 7 & 9 \\
\hline Timber $^{b}$ & 0 & 0 & 2 & 2 \\
\hline Aquaculture & 4 & 0 & 1 & 5 \\
\hline Structures/property ${ }^{\circ}$ & 3 & 1 & 2 & 6 \\
\hline Agriculture & 2 & 4 & 8 & 14 \\
\hline Rice & 3 & 0 & 1 & 4 \\
\hline Sunflower & 0 & 1 & 1 & 2 \\
\hline Corn & 1 & 1 & 1 & 3 \\
\hline Population modeling/census & 1 & 1 & 3 & 5 \\
\hline Economics & 1 & 2 & 4 & 7 \\
\hline Wildlife diseases & 3 & 2 & 4 & 9 \\
\hline Invasive species & 0 & 3 & 8 & 11 \\
\hline Damage assessments & 0 & 0 & 2 & 2 \\
\hline Roost management & 9 & 4 & 0 & 13 \\
\hline Urban settings ${ }^{d}$ & 3 & 1 & 5 & 9 \\
\hline Aquatic mammals & 3 & 1 & 4 & 7 \\
\hline
\end{tabular}

"Numbers refer to the frequency each industry/resource was specifically mentioned by 59 total respondents that identificd $3-5$ needs per state.

bDoes not include beaver.

'Utility poles, homes, and water craft.

${ }^{\mathrm{d}}$ Deer, armadillo, geese, and predators.

eBeaver, nutria, and muskrats.

priorities focused on research associated with fish-eating birds and aquaculture, blackbirds and agriculture, beavers in agricultural and riverine habitats, as well as urban issues related to wildlife-borne diseases and bird roosts. In contrast, WS Western Region priorities focused on predation on livestock and native wildlife, birds and aviation, blackbirds and agriculture, ungulates and timber, and rodents and agriculture, as well as issues related to urban bird roost management and population monitoring of overabundant wildlife species. Priority research identified by NWRC scientists encompassed all priority issues identified by WS operations. Research needs identified by the NWSAC also focused on finding methods (primarily non-lethal) to resolve bird problems in agricultural and in suburban settings and to resolving a variety of mammal damage problems including beaver, nutria, predators, feral pigs, wolves and armadillos (Table 8).

\subsection{Comparison with other surveys}

The issues identified in this 2001 assessment in some ways closely parallel those identified in earlier published assessments. Smith (1974) summarized the animal damage control research priorities of the Bureau of Sport Fisheries and Wildlife (former administrative home of the WS program) as
Table 7

Specific highest priority areas of research important to the Wildlife Services eastern and western wildlife managers and National Wildlife Research Center scientists as identified in the 2001 Wildlife Services research needs assessment

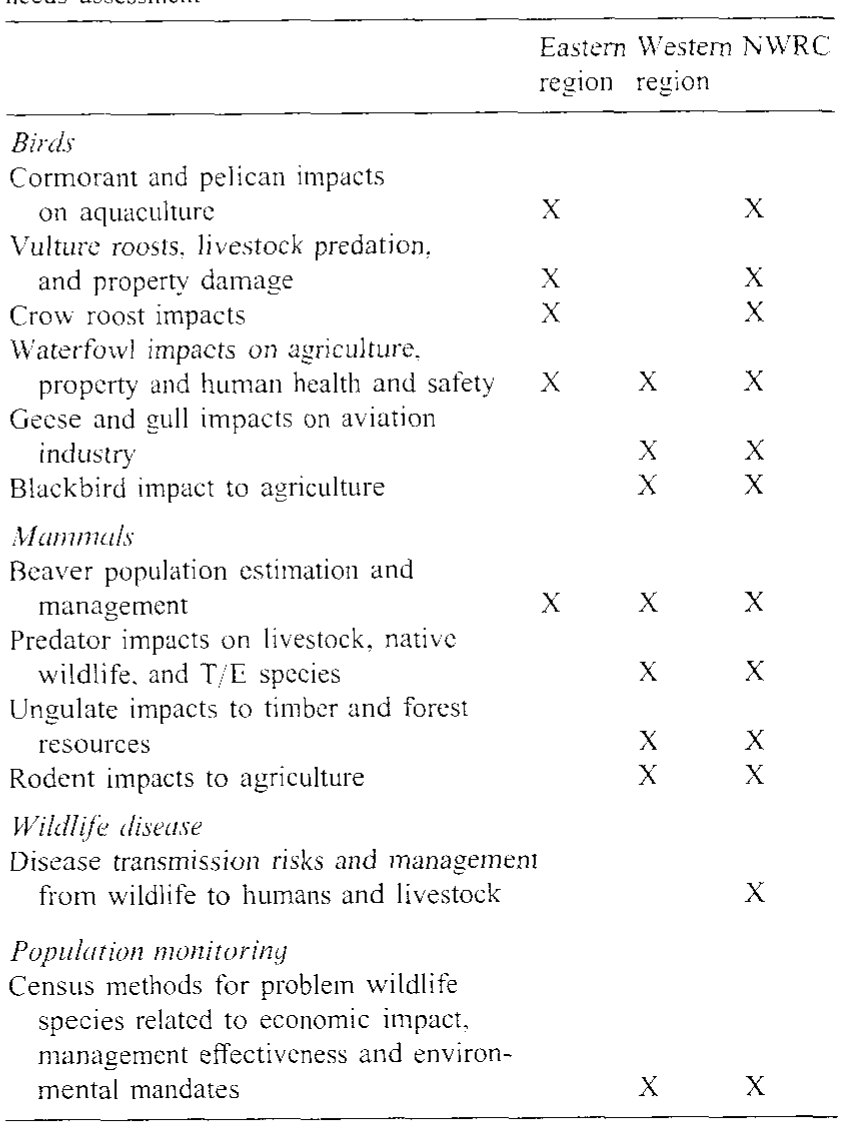

Table 8

Priority areas of research important to Wildlife Services National Advisory Committee as identified in the 2001 Wildife Services/Research Needs Assessmient

Birds

Raven repellents

Methods to manage crows and pigeons in urban areas

Methods to manage waterfowl (geese) related to human heaith and safety in urban areas

Methods to mange bird (wildlife) problems at airports

Methods to manage bird problems to agriculture

Evaluation of the impact of agricultural pesticides on bird populations

Manmals

Methods to manage prairie dogs

Methods to manage predators

Methods to manage beaver

Cost-effective methods to manage nutria

Improved methods to manage feral pigs

Improved methods to manage armadillo

New methods to manage mammal predation on threatened and endangered species

Management methods for re-established wolf populations Management methods for diseases transmitted from wildlife to humans 
principally predators, birds, and small mammals and emphasized the determination of their impacts on livestock, agricultural crops and the development of methodology to deter damage. Smith believed there was little difficulty in setting research priorities once a damage problem was identified, but that it was considerably more difficult to determine the relative distribution of resources for research on each of the three vertebrate damage groups. Spencer (1983) surveyed 31 eastern state wildlife agencies to rank the importance of the animal species about which damage complaints were received. Deer, beaver, black bear, raccoon, alligator and coyotes were of high importance among these states based on staff time devoted to problem resolution. Snakes, squirrels, geese, feral dogs, muskrats, starlings and blackbirds, skunks and opossums also occurred in the top problem listings by some states. Spencer also indicated that gulls were emerging as a problem species in and around airports. A 1997 survey on top priority eastern wildlife species, damage issues and research priorities included in a report by Regan et al. (1998), showed the increasing importance of "new" problems beyond traditional agricultural issues. These new problems included wildlife issues related to turfgrass damage, water quality effects, aircraft safety, endangered species, aquaculture and sport fisheries, and vehicle collisions. In addition, human dimensions research on public attitudes about nuisance wildlife and lethal control, customer expectations, and marketing programs were cited in this survey as important research priorities by eastern region respondents.

\section{The need for new skills and interdisciplinary research}

Curnow (2001) has recently stated, "...because of the boundless propensity of mankind to develop, inhabit and alter the landscape, wildlife managers of today and the future require different strategies, tools and skills than those who did such a fine job of conservation and management in past decades". Curnow (2001) also highlighted the evolution of changing wildlife-human conflicts. He indicated that research needs would focus on (a) urban/suburban areas with a resultant critical need for management methods acceptable in urban settings; (b) zoonotic diseases vectored by wildlife; (c) overabundant/eruptive wildlife populations; (d) human health and safety; and (e) invasive species. He also identified a number of new skills needed by future wildlife managers to effectively provide integrated, science-based solutions to these new and diverse wildlife situations. The requirement for new skills needed to address the changing nature of wildlife-human conflict resolution is evident in the increasingly interdisciplinary expertise of NWRC research staff over the past $20 \mathrm{yr}$. While NWRC still has a number of wildlife biologists, staff expertise extends to animal behavior, analytical chemistry, engineering, molecular biology, reproductive physiology and immunology, psychology, physiology, economics, statistics, veterinary medicine, chemical vaccine development and registration, and infor- mation transfer. As this 2001 RNA attests, wildlife-human conflict resolution, while still retaining some of its traditional focus, is acquiring many more complex issues and developing many more unique methods to resolve them.

\section{Acknowledgements}

The authors are appreciative of the full support of USDA/APHIS-Wildlife Service program management in conducting this survey. We wish to thank many individuals of the WS program who responded to this survey and identified their important research needs. We also wish to thank R. Curnow, M. Tobin, J.R. Mason, and K. Fagerstone for reviewing drafts of this manuscript.

Mention of companies or commercial products does not imply recommendation or endorsement by USDA over others not mentioned. USDA neither guarantees nor warrants the standard of any product mentioned. Product names are mentioned solely to report factually on available data and to provide specific information.

\section{References}

Acord, B.R., Ramey, C.A., Werge, R.W., 1994. Charting a future: process and promise. Proceedings of the Vertebrate Pest Conference, Vol. 16 University of California, Davis, CA, USA, pp. 8-11.

Bruggers, R.L., Owens, R., Clay, W.H., Reynolds, R., 1996. Research needs assessment. USDA/animal damage control program methods development. Unpublished Report, National Wildlife Research Center, Denver, CO, USA, pp. 4, and Appendices I-1II.

Bruggers, R.L., Owens, R.. Hoffman, T., 2001. Research needs assessment. USDA/APHIS/Wildlife Services. Unpublished Report, National Wildlife Research Center, Fort Collins, CO, USA, pp. 4, and Appendices I-V.

Conover, M.R., 1997. Wildlife management practices by metropolitan residents in the United States: practices, perceptions, costs, and values. Wildlife Society Bulletin 25 (2), 306-311.

Conover, M.R., 1998. Perceptions of American agricultural producers about wildlife on their farms and ranches. Wildlife Society Bulletin 26 (3), 597-604

Conover, M.R., 2001. Resolving Human-Wildlife Conflicts-The Science of Wildlife Damage Management. Lewis Publishers, CRC Press LLC, Boca Raton, FL, USA, pp. 418.

Conover, M.R., Pitt, W.C., Kessler, K.K., DuBow, T.J., Sanborn, W.A., 1995. Review of human injuries, ilinesses, and economic losses caused by wildlife in the United States. Wildlife Society Bulletin 23 (3), $407-414$.

Curnow, R.D., 1996. Introducing the National Wildlife Research Center. Proceedings of the Vertebrate Pest Conference, Vol. 17. University of California, Davis, CA, USA, pp. 6-7.

Curnow, R.D., 2001. What are the research needs and skills of the future? Proceedings of the Eastern Wildlife Damage Management Conference, Vol. 9. The Pennsylvania State University, University Park, PA, USA, pp. 18-22.

Fall, M.W., Jackson, W.B., 1998. A new era of vertebrate pest control? An introduction. International Biodeterioration \& Biodegradation 42 (2-3), 85-91.

Fall; M.W., Jackson, W.B.; 2000. Future technology for managing problems with vertebrate pests and over-abundant wildlife-an introduction. International Biodeterioration \& Biodegradation 45 (3-4), 93-95. 
Johnston, J., Volz, S., Bruce, K., Chipman, R., Luchsinger, J., McConnell, J., Owens, R., 1999. Information transfer for wildlife management. Wildlife Society Bulletin 27 (4), 1043-1049.

Messmer, T.A., 2000. The emergence of human-wildlife conflict management: tuming challenges into opportunities. International Biodeterioration \& Biodegradation 45 (3-4), 97-102.

Packham, C.J., Connolly, G., 1992. Control methods research priorities for animal damage control. Proceedings of the Vertebrate Pest Conference, Vol. 15. University of California, Davis, CA, USA, pp. 12-16.

Regan, R., Chipman, R., Lapisky, M., May, D., O'Neil, P., Organ, J., Parsons, G., Rego, P., Royar, K., Slate, D., Stang, K., 1998. Proposal for a Northeast Wildlife Damage Management Research and Outreach Cooperative. Northeast Association of Fish and Wildlife Agencies, Inc., Hadley, MA, USA, pp. 12, and Appendix I.
Smith. R.N., 1974. Animal damage control research-"Are present priorities based on actual need?" Proceedings of the Vertebrate Pest Conference, Vol. 6. Anaheim, CA, LSA, pp. 82-84.

Spencer, D.A., 1983. Animal damage control in Eastern United States. Proceedings of the Eastern Wildlife Damage Control Conference, Vol. 1. Conell Liniversity, Ithaca, New York, USA, pp. 17-25.

US Department of Agriculture, 1998. Wildlife Services: mission, strategy, and goals. Animal and Plant Health Inspection Service, Program Aid. No. 1523. Riverdale, MA.

US Department of Agriculture, 1999. National Wildlife Research Center. Animal and Plant Health Inspection Service, Miscellaneous Publication No. 1544, Riverdale, MA, pp. 8.

Wywialowski, A.P., 1994. Agricultural producers' perceptions of wildlife-caused losses. Wildlife Society Bulletin 22 (3), 370-382. 